\title{
Korelasi Variasi Gaya Mengajar Guru dengan Hasil Belajar Peserta Didik Kelas VII SMP Negeri 2 Belitang Mulya
}

\author{
Sigit Priyono $^{1 *}$, Eka Marwati ${ }^{2}$, dan Fitri Anggraini ${ }^{3}$ \\ ${ }^{1,2}{ }^{3}$ STKIP Nurul Huda \\ *E-mail: sigitpriyono@stkipnurulhuda.ac.id
}

\begin{abstract}
Abstrak: Penelitian ini dilatarbelakangi konsep bahwa variasi gaya mengajar guru sangat berpengaruh terhadap hasil belajar siswa selain faktor eksternal lainnya. Tujuan yang ingin dicapai dalam penelitian ini adalah untuk mengetahui korelasi gaya mengajar guru dengan hasil belajar IPS peserta didik kelas VII di SMPN 2 Belitang Mulya. Adapun subjek dalam penelitian ini adalah kelas VII di SMPN 2 Belitang Mulya yang berjumlah 32 siswa. Alat ukur yang digunakan untuk mengungkap variabel penelitian ini ada 2 macam alat ukur, yaitu : (1) instrumen anget dan (2) hasil belajar. Analisis akhir dalam penelitian ini menggunakan analisis regresi sederhana. Hasil penelitian menunjukkan bahwa korelasi gaya mengajar guru dengan hasil belajar IPS peserta didik kelas VII di SMP N 2 Belitang Mulya bersifat positif. Berdasarkan hasil uji $t$ diketahui bahwa secara parsial diperoleh $t_{\text {hitung }}$ sebesar 2,0 dengan probabilitas $0,000 \leq 0,05$ untuk variabel gaya mengajar guru terhadap hasil belajar siswa kelas VII SMP N 2 Belitang Mulya. Dengan demikian berarti terdapat korelasi yang signifikan antara gaya mengajar guru dengan hasil belajar siswa kelas VII SMP N 2 Belitang Mulya. Hal ini dapat dibuktikan dengan besarnya $\mathrm{t}_{\text {tabel }}<\mathrm{t}_{\text {hitung }}$ yaitu $0,349 \leq 2,0$ dengan nilai signifikasi 0,000 $\leq 0,05$, maka Ho ditolak dan $\mathrm{H} 1$ diterima dan terdapat pengaruh sebesar $34,3 \%$ dan selebihnya $66,7 \%$ dipengaruhi oleh faktor lain diluar penelitian ini.
\end{abstract}

Kata Kunci: Hasil Belajar, Gaya Mengajar.

UTILITY: Jurnal IImiah Pendidikan dan Ekonomi

Website : http://journal.stkipnurulhuda.ac.id/index.php/utility

Permalink: https://journal.stkipnurulhuda.ac.id/index.php/utility/article/view/282

How to cite (APA): Priyono, S., Marwati, E., \& Anggraini, F. (2018, February 1). Korelasi Variasi Gaya Mengajar Guru dengan Hasil Belajar Peserta Didik Kelas VII SMP Negeri 2 Belitang Mulya. UTILITY: Jurnal IImiah Pendidikan Dan Ekonomi, 2(1), 30-43.

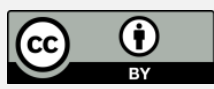

This is an open access article distributed under the terms of the Creative Commons Attribution 4.0 International License, which permits unrestricted use, distribution, and reproduction in any medium, provided the original work is properly cited.

\section{PENDAHULUAN}

Pendidikan merupakan usaha sadar yang dilakukan oleh manusia agar dapat mengembangkan potensi dirinya melalui proses pembelajaran. Pendidikan mengemban tugas untuk menghasilkan sumber daya manusia yang 
berkualitas bagi pembangunan Bangsa dan Negara. Dalam UU No. 20 Tahun 2003 tentang sistem pendidikan nasional dalam Bab IV Pasal 3 dijelaskan bahwa pendidikan nasional berfungsi mengemban kemampuan dan membentuk watak serta peradaban bangsa yang bermartabat dalam rangka mencerdaskan kehidupan bangsa, bertujuan untuk berkembangnya potensi peserta didik agar menjadi manusia yang beriman dan bertaqwa kepada Tuhan Yang Maha Esa, berakhlak mulia, sehat, berilmu, cakap, kreatif, mandiri, dan menjadi warga negara yang demokratis serta bertanggung jawab.

Dalam pencapaian tujuan belajar di SMPN 2 Belitang Mulyo ada beberapa faktor yang mempengaruhinya. Faktor-faktor tersebut adalah faktor internal dan faktor eksternal. Faktor internal merupakan faktor yang berasal dari dalam diri peserta didik, sedangkan faktor eksternal merupakan faktor yang berasal dari luar peserta didik. Salah satu faktor internal yang besar pengaruhnya terhadap hasil belajar adalah gaya guru dalam mengajar. Guru dapat menggunakan gaya mengajar dengan baik dapat diketahui melalui 4 kompetensi yaitu : 1). Menguasai bahan pelajaran sehingga dapat mengkomunikasikan bahan pembelajaran kepada peserta didik. 2). Memiliki kemampuan mendiagnosis tingkah laku peserta didik melalui komunikasi aktif. 3). Memiliki kemampuan melaksanakan proses pembelajaran secara aktif sekaligus dapat berkomunikasi aktif dengan seluruh civitas academica. 4). Memiliki kemampuan mengukur hasil belajar peserta didik untuk kemudian mengkomunikasikannya demi tindak lanjut yang akan diberikan kepada peserta didik. (Glasser, dalam Sudjana, 2014: 18).

Berdasarkan survei dari peneliti diperoleh informasi bahwa pada pembelajaran IPS di SMPN 2 Belitang Mulya bahwa guru menerapkan gaya mengajar konvensional. Gaya mengajar konvensional dalam penelitian ini yaitu gaya mengajar yang selalu berpusat pada guru. Contohnya: gaya mengajar dengan ceramah, guru sebagai pusat kegiatan belajar. Sehingga menimbulkan kebosanan peserta didik di SMPN 2 Belitang Mulya. Kondisi yang ada di SMPN 2 Belitang Mulya bahwa peserta didik saat mengikuti kegiatan pembelajaran IPS memerlukan penerapan variasi gaya mengajar pada pembelajaran IPS di SMPN 2 Belitang Mulya. Gaya mengajar yang dimaksud dalam penelitian ini yaitu demokratis, otoriter dan gaya mengajar bebas. Kegunaan penerapan gaya mengajar ini untuk menciptakan interaksi edukatif bersama peserta didik di SMPN 2 Belitang Mulya. Jika gaya mengajar guru pada pembelajaran IPS di SMPN 2 Belitang Mulya menarik dan variatif, maka peserta didik akan 
memiliki sikap positif dalam belajar. Hal ini meningkatkan pemahaman terhadap materi pembelajaran dan ketercapaian hasil belajar secara maksimal.

\section{METODE}

Penelitian ini dilihat dari analisis data digunakan digolongkan kedalam penelitian kuantitatif karena analisis data dilakukan secara kuantitatif Metode yang digunakan dalam penelitian ini adalah metode deskriptif kuantitatif. Metode analisis data dengan cara menganalisis data kuantitatif yang diperjelas dari hasil penelitian berupa data dan informasi mengenai permasalahan yang dibahas. Penelitian lapangan ini dilakukan oleh penulis untuk mengetahui langsung kepada obyek yang akan diteliti. Sesuai dengan masalah yang hendak diteliti, metode penelitian ini digunakan desain korelasional. Sukardi (2008:166) menyatakan, "Penelitian korelasional merupakan bagian penelitian ex post facto karena tidak memanipulasi keadaan variabel dan langsung mencari tingkat hubungan variabel yang direfleksikan pada koefisien korelasi”. Desain penelitian korelasi sebagaimana tersebut dapat digambarkan sebagai berikut:

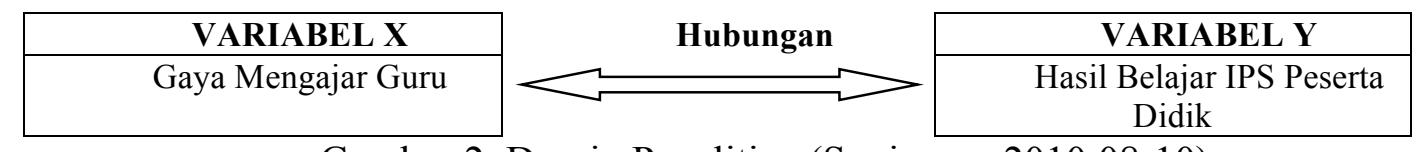

Gambar 2. Desain Penelitian (Sugiyono, 2010:08-10)

Menurut Sugiyono (2013: 63) "variabel penelitian adalah suatu atribut atau sifat atau nilai dari orang, obyek, atau kegiatan yang mempunyai variasi tertentu yang ditetapkan oleh peneliti untuk dipelajari dan ditarik kesimpulannya". Variabel yang digunakan dalam penelitian ini terdiri atas variabel bebas dan variabel terikat, dimana variabel bebasnya adalah gaya mengajar guru $(\mathrm{X})$ dan variabel terikatnya adalah hasil belajar mata pelajaran IPS peserta didik Kelas VII SMP N 2 Belitang Mulyo (Y). Dan hubungan kedua variabel berbentuk korelasional

Penelitian dilaksanakan terhadap kumpulan objek penelitian yang disebut dengan populasi. Sukmadinata (2015:250) menjelaskan, "Kelompok besar dan wilayah yang menjadi lingkup penelitian". Populasi dalam penelitian ini adalah seluruh peserta didik kelas VII SMP Negeri 2 Belitang Mulya Kabupaten OKU Timur Tahun Pelajaran 2016/2017 yang berjumlah 192 peserta didik dan terbagi 
dalam 6 kelas. Lebih jelasnya populasi pada penelitian ini disajikan pada tabel 1 .

Tabel 1 Populasi Penelitian

\begin{tabular}{ccccc}
\hline \multirow{2}{*}{ No } & Kelas & \multicolumn{2}{c}{ Jenis Kelamin } & \multirow{2}{*}{$\begin{array}{c}\text { Total } \\
\text { Jumlah }\end{array}$} \\
\cline { 3 - 4 } & & Laki-laki & Perempuan & 32 \\
\hline 1 & VII-1 & 15 & 17 & 35 \\
\hline 2 & VII-2 & 15 & 20 & 30 \\
\hline 3 & VII-3 & 16 & 14 & 30 \\
\hline 4 & VII-4 & 16 & 14 & 30 \\
\hline 5 & VII-5 & 18 & 12 & 35 \\
\hline 6 & VII-6 & 17 & 18 & $\mathbf{1 9 2}$ \\
\hline
\end{tabular}

Sumber: TU SMP Negeri 2 Belitang Mulya 2016

Pengumpulan data dalam penelitian ini bertujuan untuk memperoleh data yang sebenarnya dengan arti tidak ditambah dan tidak dikurang. Bentuk data yang dipakai dalam penelitian ini adalah data berupa hasil belajar siswa dan hasil angket, sehingga teknik pengumpulan data yang akan digunakan dalam penelitian ini adalah tes dan dengan penyebaran angket.

a. Tes Hasil Belajar

Menurut Sukmadinata (2015:223) "Tes hasil belajar disebut juga tes prestasi belajar yaitu tes yang digunakan untuk mengukur hasil-hasil belajar yang dicapai peserta didik selama kurun waktu tertentu". Instrumen tes disusun sebanyak 25 nomor dengan 4 pilihan yaitu a, b, c, dan d. Apabila peserta didik menjawab benar mendapatkan skor 1 dan jika salah mendapatkan skor 0 .

b. Gaya Mengajar

Penerapan gaya mengajar guru dalam penelitian ini di ukur melalui persepi peserta didik dengan memberikan angket. Angket persepsi peserta didik tentang gaya mengajar guru berdasarkan kisi-kisi angket dengan indikator:

Setelah data dikumpulkan, maka perlu dilakukan uji keabsahan data melalui uji validitas dan reliabilitas. Hal ini dikarenakan bahwa Instrumen penelitian yang digunakan untuk mengumpulkan data harus tepat dan relevan dengan variabel dan masalah yang dibahas. Namun sebelum itu soal angket di uji validitas dan reabilitas terlebih dahulu dengan menggunakan rumus masing- 
masing. Perhitungan validitas butir soal menggunakan rumus korelasi product moment. Butir soal yang diuji berjumlah 25 butir. Hasil perhitungan diperoleh harga $r_{\text {hitung }}$ antara 0,22 sampai 0,94 . Kemudian hasil perhitungan tersebut dibandingkan dengan tabel $r$ product moment pada taraf signifikansi $5 \%$. Kriteria soal valid jika $r_{\text {hitung }}>r_{\text {tabel }}$. Dari 25 soal tersebut, terdapat 24 soal pilihan ganda yang valid dan terdapat 1 soal pilihan ganda yang tidak valid, karena $r_{\text {hitung }}>r_{\text {tabel }}$. Maka keseluruhan dari 24 soal yang valid tersebut dapat digunakan dalam pengumpulan data dan diperoleh nilai $r_{\text {tabel }} 0,374$. Begitu juga untuk angket tersebut menunjukan bahwa semua (20) item pertanyaan memiliki koefisien validitas lebih dari 0,374 maka instrumen tersebut dinyatakan valid sehingga instrumen tersebut dapat digunakan sebagai alat ukur penelitian.

Reliabilitas butir soal dihitung dengan menggunakan rumus R11 (Spearman-Brown). Perhitungan reliabilitas soal dapat dilihat pada lampiran 10. Menurut Siregar (2013:73) kriteria suatu instrumen dikatakan reliabel apabila koefesien reliabilitasnya $\left(\mathrm{r}_{11}\right)>0,7$. Perhitungan reliabilitas disajikan pada tabel 4

Tabel 2 Daftar Hasil Perhitungan Reliabilitas Soal

\begin{tabular}{ccc}
\hline $\mathbf{r}_{\text {hitung }}$ & Syarat Reliabel & Keputusan \\
\hline 0,94 & $\mathrm{r}_{11}>0,7$ & Reliabel \\
\hline
\end{tabular}

Dari hasil perhitungan uji reliabilitas maka instrumen penelitian dinyatakan reliabel. Begitu juga angket diperoleh koefisien reliabilitas soal 0,875. Menurut Siregar (2013:73) kriteria suatu instrumen dikatakan reliabel apabila koefesien reliabilitasnya $\left(r_{11}\right)>0,349$. Berdasarkan pendapat Siregar, maka instrumen reliabel.

Tabel 3 Daftar Hasil Perhitungan Reliabilitas Angket

\begin{tabular}{ccc}
\hline $\mathbf{r}_{\text {hitung }}$ & Syarat Reliabel & Keputusan \\
\hline 0,875 & $\mathbf{r}_{11}>0,349$ & Reliabel
\end{tabular}

Berdasarkan perhitungan validitas dan reliabelitas intrumen tersebut, maka instrumen tersebut dapat digunakan pada sampel yang lebih besar untuk mengetahui apakah ada korelasi variasi gaya mengajar guru dengan hasil belajar peserta didik kelas VII di SMP N 2 Belitang Mulya. 


\section{HASIL DAN PEMBAHASAN}

\section{Hasil Penelitian}

Analisis data penelitian untuk hasil belajar dapat dicari dengan cara yaitu membuat daftar distribusi frekuensi, menghitung nilai rata-rata (mean), standar deviasi dan menentukan kategori tinggi, sedang, dan rendah. Data yang diperoleh dari tes hasil belajar IPS memperoleh nilai rata-rata (mean) sebesar 73,625 dengan nilai standar deviasi sebesar 10,54 begitu juga untuk data angket diperoleh nilai rata-rata (mean) sebesar 56,875 dan dibulatkan menjadi 56,88 dengan nilai standar deviasi diperoleh nilai 9,713.

Uji normalitas data dilakukan sebelum pengujian hipotesis. Uji normalitas digunakan untuk mengetahui populasi data berdistribusi normal atau tidak. Pada penelitian ini, pengujian normalitas data menggunakan uji kemiringan kurva. Syarat uji normalitas adalah diketahuinya nilai mean, modus dan standar deviasi data. Berdasarkan analisis data diketahui bahwa nilai mean data hasil belajar adalah 73,63 dan nilai standar deviasi data hasil belajar adalah 10,54.

Mean dan standar deviasa data telah diketahui, sedangkan modus masingmasing kelompok data belum diketahui, maka terlebih dahulu peneliti menghitung nilai modus data masing-masing kelompok data. Berikut hasil perhitungan modus data :

$$
\begin{aligned}
\mathrm{M}_{\mathrm{o}} & =\mathrm{b}+\mathrm{p}\left(\frac{b 1}{b 1+b 2}\right) \\
& =75,5+6\left(\frac{2}{2+2}\right) \\
& =78,5+6\left(\frac{2}{4}\right) \\
& =78,5+6(0,5) \\
& =78,5+3,0 \\
\mathrm{M}_{\mathrm{o}} & =81,5
\end{aligned}
$$

Prasyarat uji normalitas telah diketahui nilainya, kemudian dilakukan uji normalitas data dengan menggunakan rumus kemiringan kurva.

$$
\begin{aligned}
\mathrm{Km} & =\frac{\mathrm{Mx}-\mathrm{Mo}}{\mathrm{SD}} \\
& =\frac{73,63-81,5}{10,54}
\end{aligned}
$$




$$
\begin{aligned}
& =\frac{-7,87}{10,54} \\
& =-0,746(\text { diantara }-1 \text { dan }+1)
\end{aligned}
$$

Berdasarkan hasil uji kemiringan kurva pada data hasil belajar diperoleh harga $\mathrm{Km}=-0,746,(-1 \leq 0,746 \leq+1)$. Menurut Sudjana (2005:77) data dikatakan berdistribusi normal jika harga Km berada diantara harga -1 dan +1 .

Analisis akhir dalam penelitian ini menggunakan analisis regresi sederhana. Setelah diketahui nilai a dan b langkah selanjutnya adalah menghitung persamaan regresinya. Berdasarkan perhitungan analisis regresi sederhana diperoleh persamaan sebagai berikut :

$$
\begin{aligned}
& \hat{Y}=a+b X \\
& \hat{Y}=917,22+0,372 \times 73,63 \\
& \hat{Y}=917,22+27,39 \\
& \hat{Y}=944,61
\end{aligned}
$$

Berdasarkan perhitungan regresi tersebut diatas ditemukan bahwa korelasi antara kedua variabel bersifat positif antara penggunaan gaya mengajar dengan hasil belajar. Dengan demikian dapat dikatakan bahwa terdapat korelasi variasi gaya mengajar yang signifikan terhadap hasil belajar siswa pada mata pelajara IPS dikelas VII SMP N 2 Belitang Mulya Tahun Pembelajaran 2017/2018.

Pengujian hipotesis digunakan untuk mengetahui ada tidaknya pengaruh yang signifikan antara gaya mengajar guru $(\mathrm{X})$ dengan hasil belajar siswa (Y). Pengujian hipotesis dalam penelitian ini menggunakan Uji t. Berdasarkan hasil uji $\mathrm{t}$ diketahui bahwa secara parsial diperoleh $\mathrm{t}_{\text {hitung }}$ sebesar 2,0 dengan probabilitas $0,000 \leq 0,05$ untuk variabel gaya mengajar guru terhadap hasil belajar siswa kelas VII SMP N 2 Belitang Mulya. Dengan demikian berarti terdapat korelasi yang signifikan antara gaya mengajar guru dengan hasil belajar siswa kelas VII SMP N 2 Belitang Mulya. Hal ini dapat dibuktikan dengan besarnya $t_{\text {tabel }}<t_{\text {hitung }}$ yaitu $0,349 \leq 2,0$ dengan nilai signifikasi $0,000 \leq 0,05$, maka Ho ditolak dan $\mathrm{H} 1$ diterima.

Harga $\mathrm{R}^{2}$ atau koefisien diterminan dipergunakan untuk mengetahui besarnya sumbangan atau kontribusi yang diberikan oleh variabel gaya 
mengajar guru terhadap hasil belajar IPS pserta didik kelas VII di SMP N 2 Belitang Mulia secara simultan. Besarnya pengaruh variabel bebas terhadap variabel terikat dapat dilihat dari hasil koefisien determinasi ( $R$-square) sebesar 0,574 sehingga koefisien determinasinya adalah 34,3\%, hal ini berarti bahwa terdapat korelasi antara gaya mengajar guru dengan hasil belajar IPS peserta didik kelas VII di SMP N 2 Belitang Mulia adalah 34,3 \% dan selebihnya 66,7 $\%$ dipengaruhi oleh faktor lain diluar penelitian ini.

\section{Pembahasan}

Penelitian ini bertujuan untuk mengetahui korelasi antara gaya mengajar guru dengan hasil belajar IPS peserta didik kelas VII di SMP N 2 Belitang Mulia. Berdasarkan data penelitian yang dianalisis maka dilakukan pembahasan tentang hasil penelitian sebagai berikut.

Gaya mengajar yaitu suatu cara yang digunakan untuk menyampaikan informasi atau pesan dari guru kepada peserta didik. Guru dalam pelaksanaan kegiatan pembelajaran memiliki karakteristik tersendiri yang disebut dengan gaya mengajar. Mulyasa (2010:11) menyatakan "hakekat gaya mengajar guru adalah cara atau strategi informasi yang dimilii guru tersebut kepada peserta didik". Seorang guru harus menguasai ketarampilan dalam berbagai gaya mengajar dan harus sanggup menjalankan berbabagai peranan serta sanggup menentukan metode mengajar belajar yang paling serasi (Nasution, 2005 : 115).

Sedangkan pengertian mengajar sendiri sangat bervariasi, Menurut Setyawati (1993: 6) mengajar pada prinsipnya adalah membimbing siswa dalam kegiatan belajar mengajar atau dapat pula dikatakan bahwa mengajar merupakan suatu usaha mengorganisasikan lingkungan dalam hubunganya dengan anak didik dan bahan pengajaran sehingga menimbulkan terjadinya proses belajar pada diri siswa. Dalam definisi lain, mengajar adalah menanamkan pengetahuan, menyampaikan pengetahuan, dan kebudayaan kepada siswa serta aktiviteit mengatur lingkungan dengan baik yang menghubungkan dengan siswa sehingga terjadi proses belajar (Ahmadi, 1978 :8).

Mengajar yaitu suatu proses yang komplek yang tidak hanya sekedar menyampaikan informasi oleh guru kepada siswa tetapi banyak hal dan kegiatan yang harus dipertimbangkan serta dilakukan, sehingga mengajar dapat dikatakan suatu usaha bagaimana mengatur lingkungan dan adanya interaksi 
subjek didik atau siswa dangan lingkunganya sehingga tercipta kondisi belajar yang baik (Usman, 2010 : 19-21). Dalam proses belajar mengajar, guru mempunyai tugas untuk mendorong, membimbing dan memberi fasilitas belajar bagi siswa untuk mencapai tujuan. Guru mempunyai tanggung jawab untuk melihat segala sesuatu yang terjadi dalam kelas agar membantu proses perkembangan siswa (Slameto, 2003 : 27).

Jadi, gaya mengajar guru adalah suatu tingkah laku, sikap dan perbuatan yang dilakukan oleh guru dalam melaksanakan proses pengajaran, terutama mengenai roman muka berdirinya, pandangaan mata, suara dan geraknya yang terlihat dalam setiap tindak tanduknya sebagai pancaran diri pribadinya pada waktu mengajar dan bergaul didalam kelas. Berdasarkan hasil penelitian diketahui bahwa korelasi gaya mengajar guru dengan hasil belajar IPS peserta didik kelas VII di SMP N 2 Belitang Mulya termasuk dalam kategori sedang, hal tersebut dibuktikan dengan perolehan persentase hasil tes pesrta didik dengan kategori tinggi sebesar 15,62\%, kategori sedang 65,63\% dan kategori rendah sebesar $18,75 \%$.

Menurut Dimyati dan Mudjiono (1999:3), "hasil belajar adalah hasil dari suatu interaksi tindakan belajar dan tindakan mengajar". Nana Sudjana (1999:21) menyatakan "hasil belajar adalah kemampuan kemampuan yang dimiliki siswa setelah ia memiliki pengalaman belajarnya". Hasil belajar adalah pola-pola perbuatan, nilai-nilai, pengertian-pengertian, sikap-sikap, apresiasi dan keterampilan yang berupa: (1) informasi verbal yaitu kapabilitas mengungkapkan pengetahuan dalam bentuk bahasa, baik lisan maupun tertulis, (2) keterampilan intelektual yaitu kemampuan mempresentasikan konsep dan lambang atau kemampuan melakukan aktivitas kognitif bersifat khas, (3) strategi kognitif yaitu kecakapan menyalurkan dan mengarahkan aktivitas kognitifnya sendiri, (4) keterampilan motorik yaitu kemampuan melakukan serangakaian gerak jasmani, dan (5) sikap adalah kemampuan menginternalisasi dan mengeksternalisasi nilai-nilai (Agus Suprijono, 2010: 6).

Berdasarkan pengertian-pengertian hasil belajar diatas dapat disimpulkan bahwa hasil belajar adalah hasil yang diperoleh siswa setelah melakukan kegiatan belajar baik berupa afektif, kognitif dan psikomotorik. Menurut Blomm dalam Nana Sudjana (1999:22), membagi hasil belajar menjadi 3 ranah: 1) Ranah kognitif; Berkenaan dengan hasil belajar intelektual yang terdiri dari aspek, yakni pengetahuan atau ingatan, pemahaman, aplikasi, analisis, dan 
evaluasi. 2) Ranah afektif; Berkenaan dengan sikap yang terdiri dari 5 aspek, yakni penerima, jawaban atau reaksi, penilaian, organisasi, dan internalisasi. 3) Ranah psikomotor; Berkenaan dengan hasil belajar ketrampilan dan kemampuan bertindak.

Menurut Arikunto (Samino dan Saring Marsudi 2012:48) hasil belajar adalah hasil yang dicapai seseorang setelah melakukan kegiatan belajar dan merupakan penilaian yang dicapai seorang siswa untuk mengetahui sejauh mana bahan pelajaran atau materi yang diajarkan sudah diterima siswa. Dengan demikian untuk menentukan hasil belajar yang dicapai siswa diperlukan alat evaluasi. Berdasarkan hasil penelitian yang telah dilakuan setelah pembelajaran IPS pada materi Keadaan Alam dan Aktifitas Penduduk Indonesia, diketahui bahwa perolehan skor tertinggi adalah 72 dan skor terndahnya adalah 39. Dari data tersebut diketahui bahwa nilai mean 56,88 dengan standar deviasi 9,713. Berdasarkan hasil analisis regresi sederhana antara korelasi korelasi gaya mengajar guru dengan hasil belajar IPS peserta didik kelas VII di SMP N 2 Belitang Mulya bersifat positif. Hal tersebut dibuktikan dengan diperolehnya nilai persamaan regresinya $(\hat{Y})$ sebesar 944,61 .

Hipotesis dapat diartikan sebagai suatu jawaban yang bersifat sementara terhadap permasalahan penelitian, sampai terbukti melalui data yang terkumpul (Arikunto, 2010:110). Sedangkan menurut Kerlinger (Riduan, 2010:35) bahwasanya hipotesis ditafsirkan sebagai dugaan terhadap hubungan antara dua variabl atau lebih. Sedangkan menurut Sudjana (Riduan, 2010:35) hipotesis adalah asumsi atau dugaan mengenai sesuatu hal yang dibuat untuk menjelaskan hal itu yang sering dituntut utuk melakukan pengecekannya. Berdasarkan pengertian diatas, maka dapat dikatakan bahwa hipotesis adalah suatu jawaban yang bersifat sementara terhadap permasalahan penelitian yang akan dibuktikan kebenarannya melalui penelitian.

Adapan hipotesis yang penulis ajukan dalam penelitian ini adalah terdapat korelasi antara gaya mengajar guru dengan hasil belajar IPS peserta didik kelas VII di SMP N 2 Belitang Mulya. Berdasarkan hasil uji t diketahui bahwa secara

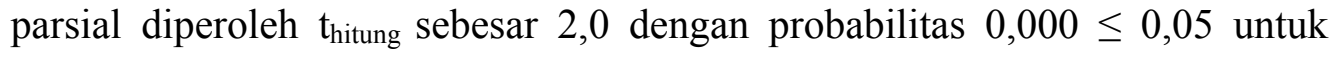
variabel gaya mengajar guru terhadap hasil belajar siswa kelas VII SMP N 2 Belitang Mulya. Dengan demikian berarti terdapat korelasi yang signifikan antara gaya mengajar guru dengan hasil belajar siswa kelas VII SMP N 2 Belitang Mulya. Hal ini dapat dibuktikan dengan besarnya $t_{\text {tabel }}<t_{\text {hitung }}$ yaitu 
$0,349 \leq 2,0$ dengan nilai signifikasi $0,000 \leq 0,05$, maka Ho ditolak dan H1 diterima dan terdapat pengaruh sebesar $34,3 \%$ dan selebihnya $66,7 \%$ dipengaruhi oleh faktor lain diluar penelitian ini.

\section{SIMPULAN}

Berdasarkan uraian pada bab-bab sebelumnya tentang korelasi gaya mengajar guru dengan hasil belajar IPS peserta didik kelas VII di SMP N 2 Belitang Mulya Tahun Pelajaran 2017/2018, maka penulis dapat menarik beberapa kesimpulan dan saran-saran yang mungkin dapat berguna bagi SMP N 2 Belitang Mulyo adalah gaya mengajar guru pada mata pelajaran IPS di kelas VII di SMP N 2 Belitang Mulya sangat bervariasi. Hal tersebut dibutikan dengan hasil penelitian diketahui bahwa korelasi gaya mengajar guru dengan hasil belajar IPS peserta didik kelas VII di SMP N 2 Belitang Mulya termasuk dalam kategori sedang dengan perolehan persentase tinggi sebesar 15,62\%, kategori sedang 65,63 \% dan kategori rendah sebesar 18,75\%. Ini berarti korelasi gaya mengajar guru dengan hasil belajar dalam kategiri sedang.

Hasil belajar setelah pembelajaran IPS pada materi Keadaan Alam dan Aktifitas Penduduk Indonesia, diketahui bahwa perolehan skor tertinggi adalah 72 dan skor terndahnya adalah 39. Dari data tersebut diketahui bahwa nilai mean 56,88 dengan standar deviasi 9,713. Berdasarkan hasil analisis regresi sederhana antara korelasi korelasi gaya mengajar guru dengan hasil belajar IPS peserta didik kelas VII di SMP N 2 Belitang Mulya bersifat positif. Hal tersebut dibuktikan dengan diperolehnya nilai persamaan regresinya ( $\hat{Y}$ ) sebesar 944,61

Korelasi gaya mengajar guru dengan hasil belajar IPS peserta didik kelas VII di SMP N 2 Belitang Mulya bersifat positif. Berdasarkan hasil uji t diketahui bahwa secara parsial diperoleh $t_{\text {hitung }}$ sebesar 2,0 dengan probabilitas $0,000 \leq$ 0,05 untuk variabel gaya mengajar guru terhadap hasil belajar siswa kelas VII SMP N 2 Belitang Mulya. Dengan demikian berarti terdapat korelasi yang signifikan antara gaya mengajar guru dengan hasil belajar siswa kelas VII SMP N 2 Belitang Mulya. Hal ini dapat dibuktikan dengan besarnya $t_{\text {tabel }}<t_{\text {hitung }}$ yaitu $0,349 \leq 2,0$ dengan nilai signifikasi $0,000 \leq 0,05$, maka Ho ditolak dan H1 diterima dan terdapat pengaruh sebesar 34,3\% dan selebihnya 66,7 \% dipengaruhi oleh faktor yang lain diluar penelitian ini. 


\section{SARAN}

Ada beberapa saran yang penulis kemukakan yang kiranya dapat menjadi masukan guna meningkatkan motivasi belajar siswa di SMP N 2 Belitang Mulya lebih baik lagi yaitu : Kepada pihak pemerintah dan para pengamat pendidikan hendaknya mengadakan seminar-seminar atau workshop yang bertemakan tentang motivasi belajar atau yang berkaitan dengan pendidikan agar menjadikan guru yang aktif, inovatif dan menyenangkan. Kepada guru bidang studi diharapkan untuk lebih memotivasi peserta didik dengan menciptakan pembelajaran yang kreatif yang dapat menimbulkan minat belajar siswa, dan seorang guru juga harus meningkatkan kualitas diri dengan memberikan teladan dan bimbingan kepada peserta didik. Kepada pihak sekolah agar lebih memperhatikan keluhan dari guru-guru dan peserta didik seperti sumber belajar atau alat belajar yang dibutuhkan dalam proses pembelajaran. Untuk para siswa agar lebih aktif dalam pembelajaran agar tercipta interaksi antara guru dengan peserta didik, sehingga dapat menciptakan suasana belajar yang menyenangkan.

\section{UCAPAN TERIMAKASIH}

Ucapan terimakasih ditujukan kepada Ketua STKIP Nurul Huda, Ketua LPPM STKIP Nurul Huda, Tim Jurnal Utility STKIP Nurul Huda, Kepala SMP Negeri 2 Belitang Mulya dan segenap dewan dosen dan staf STKIP Nurul Huda.

\section{REFERENSI}

Anaci L,Y. (2015). Pengaruh Persepsi siswa Tentang Variasi Mengajar Guru dan Cara Belajar Siswa Terhadap Hasil Belajar IPS Terpadu Siswa Kelas VIII SMP Negeri 1 Kupang. Surakarta. Prosiding Semiar Nasional Pendidikan Ekonomi \& Bisnis Fakultas Keguruan dan Ilmu Pendidikan Universitas Sebelas Maret Surakarta.

Arikunto, S. (2012). Dasar-Dasar Evaluasi Pendidikan. Jakarta: Rineka Cipta.

Artikawati, R. (2016). Pengaruh Keterampilan Mengadakan Variasi Gaya Mengajar Terhadap Prestasi Belajar Siswa Kelas IV SD. Yogyakarta. Jurnal Pendidikan Guru Sekolah Dasar UNY.

Aunurrohman. (2011). Belajar dan Pembelajaran. Bandung: Alfabeta. 
Boediono. (2014). Metode Penelitian Kuantitatif. Jakarta: Praya Media.

Danim, S. (2009). Profesionalisme Guru. Jakarta: Rineka Cipta.

Depdiknas. (2006). Pedoman Penilaian Hasil Belajar. Jakarta: Depdiknas.

Hadiatur R, M. (2016). Pengaruh Model Pembelaaran dan Gaya Mengajar Terhadap Prestasi Belajar Siswa Pada Mata Pelajaran PKN. Malang. Jurnal Penelitian dan Pendidikan IPS Universitas Kanjuruhan Malang.

Hamalik, O. (2010). Proses Belajar Mengajar. Jakarta: Bumi Aksara.

Hasibuan, N. (2013). Pengaruh Gaya Mengajar Komando dan Gaya Mengajar Resiprokal Terhadap Peningkatan Kesegaran Jasmani dan Kognitif. Medan. Jurnal Penelitian FIK Universitas Negeri Medan.

Mudyoharjo, R. (2009). Ilmu Pendidikan. Jakarta: Raja Grafindo Persada.

Mulyasa, E. (2010). Menjadi Guru Profesional. Bandung: Remaja Rosdakarya.

Riduwan. (2011). Dasar-dasar Statistika. Bandung: Alfabeta.

Sa'ud \& Udin, S. (2010). Strategi Pengembangan Konsep Belajar. Jakarta: Pustaka Prestasi.

Septiana A, \& Cintya. (2013). Pengaruh Gaya Mengajar Guru dan Gaya Belajar Siswa Terhadap Hasil Belajar Mata Pelajaran Ekonomi Di Kelas X SMA Negeri 18 Surabaya. Surabaya. Jurnal Penelitian Fakultas Ekonomi Universitas Negeri Surabaya.

Santyasa, U. (2009). Penilaian Hasil Belajar. Jakarta: Rineka Cipta.

Somantri \& Jujun, S. (2008). Aplikasi Pembelajaran IPS. Jakarta: Ganesha.

Sudijono, A. (2010). Pengantar Statistik Pendidikan. Jakarta: Raja Grafindo Persada.

Sudjana, N. (2014). Evaluasi Hasil Belajar. Bandung: Remaja Rosdakarya.

Sugiyono. (2010). Metode Penelitian Kualitatif, Kuantitatif dan R\&B. Bandung: Alfabeta. 
Korelasi Variasi Gaya Mengajar Guru dengan Hasil Belajar Peserta Didik Kelas VII SMP Negeri 2 Belitang Mulya

Sukardi. (2008). Metode Penelitian Kuantitatif Untuk Psikologi dan Pendidikan. Jakarta: Rineka Cipta.

Sukmadinata \& Nana, S. (2015). Metode Penelitian Pendidikan. Bandung: Remaja Rosdakarya.

Uhbiyati, U. (2008). Kurikulum Pembelajaran. Jakarta: Rineka Cipta. 